\title{
Nevus Lipomatosus Cutaneous Superficialis: Report of Eight Cases
}

Samia Goucha · Aida Khaled · Faten Zéglaoui · Soumeya Rammeh · Rachida Zermani · Bécima Fazaa

To view enhanced content go to www.dermtherapy-open.com

Received: July 8, 2011 / Published online: September 9, 2011

(c) The Author(s) 2011. This article is published with open access at Springerlink.com

\section{ABSTRACT}

Introduction: Nevus lipomatosus cutaneous superficialis (NLCS) is a rare benign hamartomatous skin tumor characterized by dermal deposition of mature adipose tissue. It's classified in two types: the classical form with multiple soft, pedunculated, cerebriform papules and nodules that coalesce into plaques, and the solitary form that consists of a solitary papule or nodule. In this study, eight cases of

Samia Goucha $(\varangle)$

Dermatology Unit, Mongi Slim Hospital, Sidi Daoud, Tunis, 2046, Tunisia. Email: samiagoucha@yahoo.fr

Aida Khaled · Faten Zéglaoui · Bécima Fazaa Department of Dermatology, Charles Nicolle Hospital, Boulevard 9 Avril Tunis, 1006 Tunisia

Soumeya Rammeh · Rachida Zermani Department of Histopathology, Charles Nicolle Hospital, Boulevard 9 Avril, Tunis, 1006 Tunisia

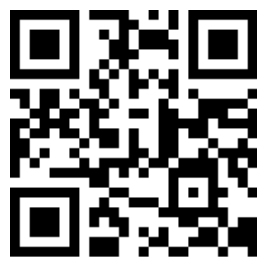

Enhanced content for this article is available on the journal web site: www.dermtherapy-open.com
NLCS are reported. Methods: The study was a retrospective case series including all patients with histopathologically documented NLCS who attended the Dermatology Department of Charles Nicolle hospital between January 1997 and December 2010. The objective of our study was to determine the epidemioclinical characteristics, the histopathologic features, and the treatment of this hamartoma. Patients included three males and five females aged between 7 and 41 years. Results: In four cases hamartoma was present since childhood, and in the other four cases it appeared in the third and fourth decades. Classical form was noted in seven cases and the solitary form in one case. Lesions involved limbs in four patients and trunk in four patients. Seven patients underwent surgical excision, and for one case no treatment was proposed. Conclusion: The multiple or classical form is largely predominant in our study. Habitually, NLCS has an asymptomatic course. Treatment is usually not necessary unless for cosmetic reasons; surgical excision is curative and recurrence after is rare.

Keywords: multiple form; nevus lipomatosus cutaneous superficialis; pedonculated lipofibroma 


\section{INTRODUCTION}

Nevus lipomatosus cutaneous superficialis (NLCS) was first described by Hoffman and Zuhrelle in $1921 .{ }^{1}$ It's a rare idiopathic hamartomatous benign condition characterized by the presence of an ectopic mature adipose tissue within the dermis. It is classified into two clinical variants: the classical form, usually composed of multiple and grouped skin-colored, pedunculated and cerebriform nodules that often coalesce to form a plaque and a second more rare form, presenting as a solitary domeshaped sessile papule or nodule. ${ }^{2-4}$ We report here eight cases of NLCS in order to assess the epidemiologic, clinical, and pathological features, as well as the management of this uncommon neoplasm.

\section{METHODS}

This study was a retrospective case series including all patients with histopathologically documented NLCS, who attended the Dermatology Department of Charles Nicolle hospital in Tunisia during the last 14 years; between January 1997 and December 2010.

Figure 1. Soft, skin-colored voluminous tumor $(10 \mathrm{~cm} \times 7 \mathrm{~cm})$ of the left buttock composed of multiple nodules with a cerebriform surface.

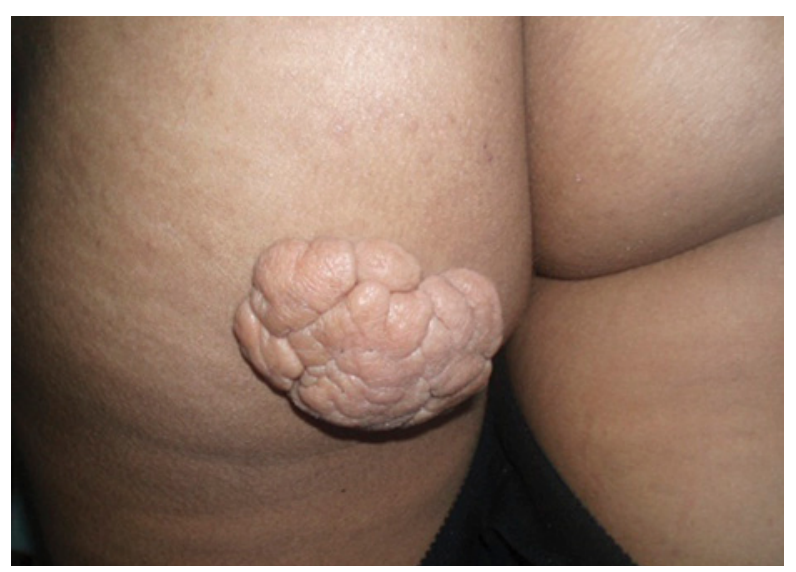

Figure 2. Multiple soft skin-colored papules and nodules coalescing into a $5 \mathrm{~cm}$ plaque.

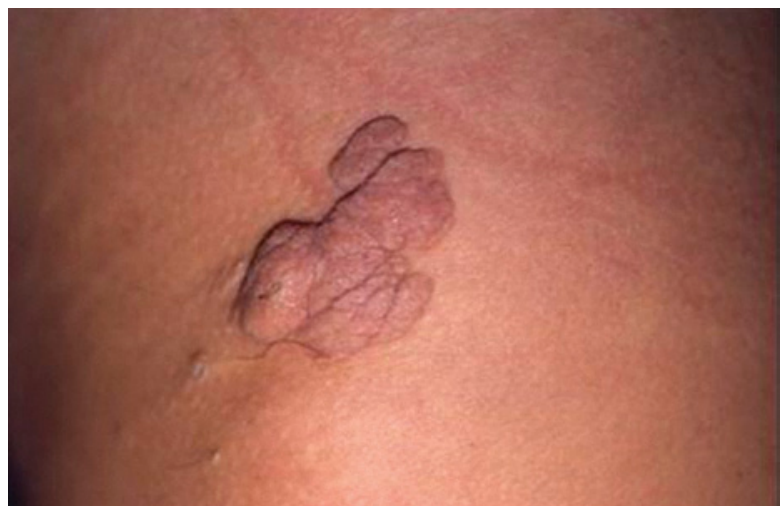

For each patient, we recorded the following data: age, sex, duration of the lesions, their localizations, number, and size as well as their management and evolution. Ethical approval and informed consent was obtained from the patients or children's parents.

\section{RESULTS}

Eight patients with NLCS were observed, three males and five females, aged between 7 and 41 years. In patients number $4,5,7$, and 8 , lesions had begun during childhood (at 1, 4, 5, and 6 years respectively). For the other four patients (number 1, 2, 3, and 6) lesions had begun in the third to fourth decade of life. Clinical presentation was that of the classical form in seven patients and of the solitary form in one patient (patient number 3). In four patients it was one of the limbs which had the lesion, and in the other four patients it was the trunk (Figure 1: patient 8; Figure 2: patient 5).

Histopathological features were typical of NLCS showing ectopic mature adipose tissue in the dermis (Figure 3). Epidermic changes were not always present.

Seven patients underwent surgical excision of the lesion. In patient number 2, no treatment was proposed. 
Table 1 summarizes the main epidemiologic, clinical and pathological features, and management of NLCS in all eight patients.

\section{DISCUSSION}

NLCS is more commonly present from birth, but can appear later in life; there is neither sex predilection nor familial trend in this disorder. ${ }^{1}$ In this study, there were five cases in which the lesion appeared in the first three decades, and in three cases NLCS appeared after 35 years. Two clinical patterns of NLCS exist; a multiple form or classical type, and the solitary form. In the classical type, lesions are congenital or they

Figure 3. Normal epidermis, mature fat cells in reticular dermis.

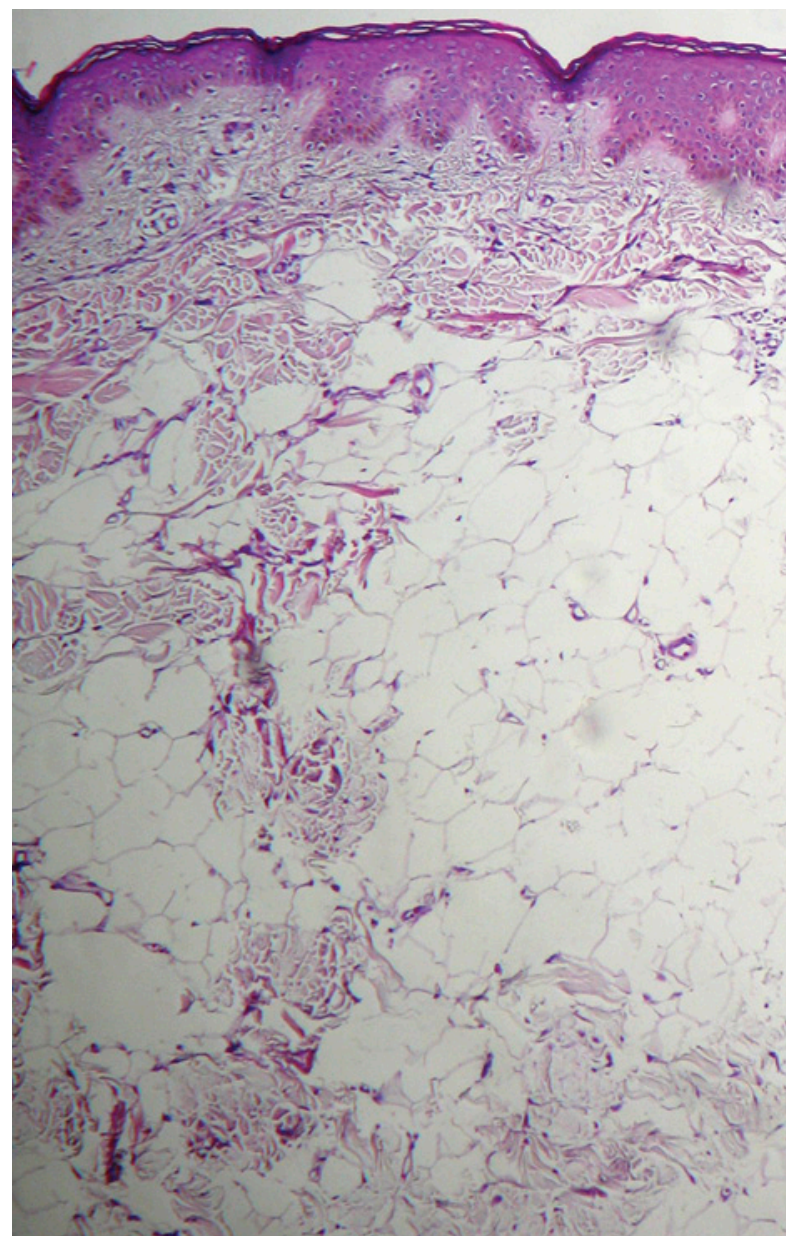

develop usually during the first two to three decades of life. ${ }^{5,6,7}$ It consists of multiple papules, skin colored or yellowish, coalescing into plaques with zosteriform, linear or segmental distribution. The lesions are slow-growing, with a smooth or cerebriform surface, and can reach a large size if left untreated. The largest size reported so far has been $40 \mathrm{~cm} \mathrm{x} 28 \mathrm{~cm} .{ }^{8}$ The most common sites are the pelvic girdle, the lower trunk, the gluteal region, and the thigh. The second clinical pattern of NLCS is a solitary papule or nodule mimicking skin tag, ${ }^{8}$ usually appearing later than the classical form, during the third to sixth decades of life. ${ }^{3,6,9}$ It can occur at any site, including unusual ones like the scalp, the eyelid, the nose, and the clitoris. ${ }^{1,10-13}$ Solitary form was also called pedonculated lipofibroma by Mehregan et al. because of its distinctive clinicopathologic features in comparison with the multiple form. ${ }^{9,14}$ Among the presented cases, there were seven cases with the classical form and one case with the solitary form (case 3), whilst in another Tunisian study the solitary type was predominant: 11 cases out of $13 .{ }^{15}$

NLCS have an indolent and asymptomatic course. Recently, a case of ulnar nerve entrapment accompanied by numbness and straining in the forearm, caused by NLCS, was reported and was treated by partial excision for symptomatic recovery. ${ }^{16}$ Occasionally, NLCS may ulcerate after external trauma or ischemia. In two previously reported cases, surface of nevus was studded with multiple open comedons, ${ }^{2,17}$ and foul-smelling discharge may be associated. ${ }^{2}$ NLCS has been reported in association with other cutaneous disorders; follicular papules and hypertrophic pilo-sebaceous units, ${ }^{18}$ angiokeratoma of Fordyce, ${ }^{4}$ scattered leukoderma, café-au-lait macules, ${ }^{2}$ and hemangioma. ${ }^{4}$ In our study, no associated skin abnormalities were present. To our knowledge, there are no systemic 
abnormalities or malignant transformation described with NLCS. NLCS should be clinically differenciated from nevus sebaceous, neurofibroma, lymphangioma, focal dermal hypoplasia, cylindroma, trichoepithelioma, and angiolipoma. Histopathological evaluation is required for diagnosis showing ectopic mature adipocytes, intermingled

Table 1. Epidemiologic, clinical and pathological features, and management of Nevus lipomatosus cutaneous superficialis (NLCS) in all eight patients.

\begin{tabular}{|c|c|c|c|c|c|c|c|}
\hline Patient & Sex & $\begin{array}{l}\text { Age } \\
\text { (years) }\end{array}$ & Duration & Location & Clinical aspect & Histopathology & Treatment \\
\hline 1 & M & 38 & 1 year & $\begin{array}{l}\text { Left } \\
\text { buttock }\end{array}$ & $\begin{array}{l}\text { Plaque of several soft skin- } \\
\text { colored nodules of } 1 \mathrm{~cm} \\
\text { to } 2 \mathrm{~cm}\end{array}$ & $\begin{array}{l}\text { Mature adipose tissue in } \\
\text { reticular dermis without } \\
\text { connection to the } \\
\text { hypodermis }\end{array}$ & $\begin{array}{l}\text { Surgical } \\
\text { resection }\end{array}$ \\
\hline 2 & $\mathrm{~F}$ & 38 & 3 months & Right thigh & $\begin{array}{l}\text { Multiple soft yellowish } \\
\text { papules coalescing into } \\
\text { plaques }\end{array}$ & $\begin{array}{l}\text { Ectopic mature } \\
\text { adipocytes in reticular } \\
\text { dermis }\end{array}$ & Abstention \\
\hline 3 & $\mathrm{~F}$ & 39 & 1 year & $\begin{array}{l}\text { Left } \\
\text { shoulder }\end{array}$ & $\begin{array}{l}\text { One soft skin-colored } \\
\text { nodule of } 1 \mathrm{~cm}\end{array}$ & $\begin{array}{l}\text { Lobular proliferation of } \\
\text { fat tissue in the dermis }\end{array}$ & $\begin{array}{l}\text { Surgical } \\
\text { resection }\end{array}$ \\
\hline 4 & M & 7 & 6 years & $\begin{array}{l}\text { Right } \\
\text { shoulder }\end{array}$ & $\begin{array}{l}\text { Large }(6 \mathrm{~cm} \times 2 \mathrm{~cm}) \text { soft } \\
\text { skin-colored verrucous } \\
\text { plaque composed of } \\
\text { nodules and papules }\end{array}$ & $\begin{array}{l}\text { Ectopic mature } \\
\text { adipocytes in reticular } \\
\text { dermis }\end{array}$ & $\begin{array}{l}\text { Surgical } \\
\text { resection }\end{array}$ \\
\hline 5 & M & 24 & 20 years & $\begin{array}{l}\text { Lumbar } \\
\text { area }\end{array}$ & $\begin{array}{l}1 \mathrm{~cm} \text { to } 3 \mathrm{~cm} \text {-grouped soft } \\
\text { skin-colored papules }\end{array}$ & $\begin{array}{l}\text { Epidermal acanthosis, } \\
\text { ectopic mature adipocytes } \\
\text { in papillary dermis }\end{array}$ & $\begin{array}{l}\text { Surgical } \\
\text { resection }\end{array}$ \\
\hline 6 & $\mathrm{~F}$ & 32 & 10 years & Thigh & $\begin{array}{l}\text { Multiple soft skin-colored } \\
\text { papules coalescing into a } \\
5 \mathrm{~cm} \text { plaque }\end{array}$ & $\begin{array}{l}\text { Epidermal acanthosis; } \\
\text { hyperkeratosis; dermal } \\
\text { proliferation of mature } \\
\text { adipocytes }\end{array}$ & $\begin{array}{l}\text { Surgical } \\
\text { resection }\end{array}$ \\
\hline 7 & $\mathrm{~F}$ & 14 & 9 years & Flank & $\begin{array}{l}\text { Large }(6 \mathrm{~cm} \times 2 \mathrm{~cm}) \\
\text { soft skin-colored plaque } \\
\text { composed of nodules }\end{array}$ & $\begin{array}{l}\text { Thinned epidermis, } \\
\text { ectopic mature adipose } \\
\text { tissue in reticular dermis }\end{array}$ & $\begin{array}{l}\text { Surgical } \\
\text { resection }\end{array}$ \\
\hline 8 & $\mathrm{~F}$ & 41 & 35 years & $\begin{array}{l}\text { Left } \\
\text { buttock }\end{array}$ & $\begin{array}{l}\text { Soft, skin-colored } \\
\text { voluminous tumor } \\
(10 \mathrm{~cm} \times 7 \mathrm{~cm}) \text { composed } \\
\text { of multiple nodules with a } \\
\text { cerebriform surface }\end{array}$ & $\begin{array}{l}\text { Normal epidermis, mature } \\
\text { fat cells in reticular dermis } \\
\text { without hypodermis } \\
\text { connection }\end{array}$ & $\begin{array}{l}\text { Surgical } \\
\text { resection }\end{array}$ \\
\hline
\end{tabular}

$\mathrm{F}=$ female; $\mathrm{M}=$ male. 
with collagen bundles, and proliferating around the periadnexial adventitial dermis and the perivascular area. Mature fat cells proliferate in reticular dermis and may extend to the papillary dermis. ${ }^{2,6,7}$ In the most characteristic feature of NLCS, there is usually no connection to the subcutaneous fat tissue; for some authors this condition is necessary to establish diagnosis of NLCS. ${ }^{6}$

Several studies documented increased vascularity in the subpapillary and papillary dermis; epidermal changes have been reported, like mild to moderate acanthosis, basket weave hyperkeratosis, increased basal pigmentation, and focal elongation of rete pegs. ${ }^{3}$ Adnexal structures may be reduced, ${ }^{3}$ and abnormal folliculosebaceous structures were reported in some cases such as sebaceous trichofolliculoma, folliculosebaceous cystic hamartoma, and dermoid cysts. ${ }^{7,19}$ In our study, diagnosis of NLCS was based on characteristic clinical aspects and confirmed by typical histopathological features. The genetic background of NLCS is still unknown, only one cytogenetic study was reported recently showing a 2p24 deletion. ${ }^{20}$

The pathogenesis of NLCS remains unknown. Several theories have been proposed: Hoffman and Zuhrelle postulated that fat deposition in the dermis is secondary to degenerative changes (metaplasia) in the connective tissue. ${ }^{3}$ Other authors hypothesized that adipocytes originate from the pericytes of dermal vessels. ${ }^{2,21}$ For others, fat cells represented a true nevus that resulted from the focal heterotopic development of adipose tissue. ${ }^{22}$ Treatment is usually not necessary unless for cosmetic reasons. The treatment of choice is surgical excision, which is curative, and post surgical recurrence is rare. Patients unwilling for surgery may undergo cryotherapy which yields partial but satisfactory results. ${ }^{8}$ Recently, a case of classic
NLCS successfully treated with $\mathrm{CO}_{2}$ laser was reported with no recurrence during a follow-up period of 12 months. ${ }^{23}$

In this retrospective study, we didn't investigate chromosomal abnormalities to identify the genetic biomarkers of this congenital pathology, since cytogenetic analysis was reported in only one previous study. ${ }^{20}$

\section{CONCLUSION}

Physicians should be aware of this rare condition because early recognition enables more conservative resection of the tumor and less invasive reconstruction of the defect. NLCS is a rare skin malformation; we report herein a large case series of eight patients where the classical form is predominant. Our study may give additional data about epidemiological and clinical pattern of this hamartoma. Further studies are needed, especially prospective studies, by using chromosomal analysis to reach conclusions about the role of the genetic abnormalities in the development of this hamartoma.

\section{ACKNOWLEDGMENTS}

Dr. Goucha declares that there is no funding or sponsorship received in relation to this paper. Dr. Goucha is the guarantor for this article, and takes responsibility for the integrity of the work as a whole. There is no other person who contributed to the manuscript, other than the authors named. All authors declare they have no conflict of interest.

Open Access. This article is distributed under the terms of the Creative Commons Attribution Noncommercial License which permits any noncommercial use, distribution, and reproduction in any medium, provided the original author(s) and source are credited. 


\section{REFERENCES}

1. Hatori R, Kubo T, Yano K, et al. Nevus lipomatosus cuataneous superficialis of the clitoris. Dermatol Surg. 2003;29:1071-1072.

2. Ghosh SK, Bandyopadhyay D, Jamadar NS. Nevus lipomatosus cutaneous superficialis: an unusual presentation. Dermatol Online J. 2010;16:12.

3. Buch Archana C, Paniker NK, Karve PP. Solitary nevus lipomatosus cutaneous superficialis. J Postgrad Med. 2005;51:47-48.

4. Al-Mutairi N, Joshi A, Nour-Eldin O. Nevus lipomatosus cutaneous superficialis of HoffmannZuhrelle with angiokeratoma of Fordyce. Acta Derm Venereol. 2006;86:92-93.

5. Yap FBB. Nevus lipomatosus superficialis. Singapore Med J. 2009;50:161-162.

6. Ioannidou DJ, Stefanidou MP, Panayiotides JG, Tosca AD. Nevus lipomatosus cutaneous superficialis (Hoffmann-Zuhrelle) with localized scleroderma like appearance. Int J Dermatol. 2001;40:54-57.

7. Brasanac D, Boricic I. Giant nevus lipomatosus superficialis with multiple folliculosebaceous cystic hamartomas and dermoid cysts. J Eur Acad Dermatol Venereol. 2005;19:84-86.

8. Khandpur S, Nagpal SA, Chandra S, Sharma VK, Kaushal S, Safaya R. Giant nevus lipomatosus cutaneous superficialis. Indian J Dermatol Venereol Leprol. 2009;75:407-408.

9. Nogita T, Wong TY, Hidano A, Mihm MC Jr, Kawashima M. Pedonculated lipofibroma. A clinicopathologic study of thirty-two cases supporting a simplified nomenclature. J Am Acad Dermatol. 1994;31:235-240.

10. Kaw P, Carlson A, Meyer DR. Nevus lipomatosus (pedonculated lipofibroma) of the eyelid. Ophtal Plast Reconstr Surg. 2005;21:74-76.

11. Mansour AT, Yasar S, Aydingos IE, Goktay F, Ozdemir N, Sungurlu F. Colocalization of lipedematous scalp and nevus lipomatosus superficialis: a case report. J Cutan Pathol. 2007;34:342-345.
12. Chanoki M, Sugamoto I, Suzuki S, Hamada T. Nevus lipomatosus cutaneous superficialis of the scalp. Cutis. 1989;43:143-144.

13. Saez Rodriguez M, Rodriguez-Martin M, Carnerero A, et al. Nevus lipomatosus cutaneous superficialis on the nose. J Eur Acad Dermatol Venereol. $2005 ; 19: 751-752$.

14. Mehregan AH, Tavafolghi V, Ghandchi A. Nevus lipomatosus cutaneous superficialis (HoffmannZuhrelle). J Cutan Pathol. 1975;2:307-313.

15. Triki S, Mekni A, Haouet S, et al. Nevus lipomatosus cutaneous superficialis: a clinico-pathological study of 13 cases. Tunis Med. 2006;84:800-802.

16. Tunce S, Sezgin B, Yilmaz G, Gocun P U, Kucuker I. Compression neuropathy caused by an unusual lesion: nevus lipomatosus cutaneus superficialis. Plast Reconstr Surg. 2011;127:72-74.

17. Ghali I, Boussofara L, Ghariani N, et al. Nevus lipomatosus cutaneous superficialis. Ann Dermatol Venereol. 2011;138:71-72.

18. Inoue M, Ueda K, Hashimoto T. Nevus lipomatosus cutaneous superficialis with follicular papules and hypertrophic pilo-sebaceous units. Int J Dermatol. 2002;41:241-243.

19. Bancalari E, Martinez-Sanchez D, Tardio JC. Nevus lipomatosus superficialis with a folliculosebaceous component : report of 2 cases. Patholog Res Int. 2011:105973.

20. Cardot-Leccia N, Italiano A, Monteil MC, Basc E, Perrin C, Pedeutour F. Nevus lipomatosus superficialis : a case report with a 2p24 deletion. $\mathrm{Br}$ J Dermatol. 2007;156:380-381.

21. Lane JE, Clark E, Marzec T. Nevus lipomatosus cutaneous superficialis Pediatr Dermatol. 2003;20:313-314.

22. Dotz W, Prioleau PG. Nevus lipomatosus cutaneous superficialis. Arch Dermatol. 1984;120:376-379.

23. Fatah S, Ellis R, Seukeran DC, Carmichael AJ. Successful CO2 laser treatment of naevus lipomatosus cutaneous superficialis. Clin Exper Dermatol. 2010,35:559-560. 